\title{
SOLUBLE INTERLEUKIN 2 RECEPTORS' LEVELS VERSUS THYROID HORMONES LEVELS IN NONTHYROIDAL DISEASE
}

\author{
Ioannis Ilias ${ }^{1}$, Georgios Panoutsopoulos ${ }^{2}$, Nikiforos Filippou ${ }^{3}$, \\ Anna Dima ${ }^{3}$, Ioulia Christakopoulou ${ }^{2}$, Paraskevi Roussou $^{4}$
}

«Sotiria» Hospital, Athens, Greece: Department of Medicine ${ }^{1}$; Department of Nuclear Medicine ${ }^{2}$; Ninth Department of Pulmonary Medicine ${ }^{3}$; Third Department of Medicine, University of Athens ${ }^{4}$

Summary: Serum soluble interleukin-2 receptor levels, basal thyrotropin, total thyroxine, total triiodothyronine and free triodothyronine were assayed in 29 - otherwise healthy - patients with pulmonary tuberculosis before initiation of anti-tuberculosis treatment and after two weeks of therapy. Twenty seven out of 29 patients presented low-normal total triiodothyronine levels, showing a statistical elevation after anti-tuberculosis therapy. Total triiodothyronine levels before anti-tuberculosis therapy were inversely correlated with levels of serum soluble interleukin-2 receptors. Further investigation on the relationship between soluble interleukin-2 receptor's levels and thyroid hormones in non-thyroidal disease can be envisaged.

Key words: Receptors; Interleukin-2; Thyroid hormones; Tuberculosis

\section{Introduction}

Antigen stimulation of resting T-cells triggers synthesis and secretion of interleukin-2, as well as the membrane expression of interleukin-2 receptors (1). Normal peripheral blood mononuclear cells and certain lines of T- and B-cell origin release, after its membrane expression, a soluble form of interleukin-2 receptor (sIL-2R); this appears to be a consequence of cellular activation of various cell types that may play a role in the regulation of the immune response $(1,2)$. Patients with autoimmune diseases, haematologic malignant diseases or overt thyroid disease often show high sIL-2R serum levels $(3,4,5)$, however the course of sIL-2R levels in non-thyroidal disease affecting thyroid function has not been adequately explored. Recent studies have shown that patients with tuberculosis (TB) present with low to normal free and total triiodothyronine levels, which rapidly elevate after anti-TB treatment $(6,7,8)$. The aim of the present study was to evaluate thyroid function parameters and/versus sIL-2R- $\alpha$ (one of the receptor's subunits) in patients with pulmonary TB before and after initiation of anti-TB therapy.

\section{Materials and methods}

Sera from 29 ambulatory patients ( 19 men, 10 women, mean age \pm SE: $36 \pm 3$ years, BMI $>26$ ) with sputum-smear positive focal pulmonary TB were assayed for sIL-2R- $\alpha$ (Quantikine hIL-2sR EIA assay, R\&D Systems, Oxon, UK, normal limits $676-2132 \mathrm{pg} / \mathrm{mL}$ ), serum basal thyrotropin (Gammacoat hTSH IRMA, INCSTAR, Stillwater, Minnesota, USA, normal limits $0.40-3.10 \mu \mathrm{IU} / \mathrm{mL}$ ), total serum thyroxine and triiodothyronine (Amerlex T4 and T3 RIA, Kodak diagnostics, Amersham, UK, normal values at 5.0$14.0 \mathrm{ng} / \mathrm{dL}$ and $0.50-1.90 \mathrm{ng} / \mathrm{mL}$ respectively) and free triiodothyronine (Free T3 Clinical Assay, INCSTAR, Stillwater, Minnesota, USA, normal limits $1.50-3.20 \mathrm{pg} / \mathrm{mL}$ ). The intra- and interassay coefficients of variation of these commercially available assays were less than 6\%. Measurements were executed twice for each patient; the first sample was obtained before anti-TB therapy and the second after two weeks of isoniazid (300 $\mathrm{mg} /$ day), rifampicin $(600$ $\mathrm{mg} /$ day) and pyrazinamide $(30 \mathrm{mg} / \mathrm{kg} /$ day) treatment. No other medications were administered during the study period.

The patients' HIV status was assessed, with their consent, using a commercial assay (HIV-1/HIV-2 $3^{\text {rd }}$ Generation Plus EIA, Abbott GmbH, Deikenheim. Germany) and none was HIV (+). Subsequent Mycobacterium tuberculosis cultures did not reveal in vitro resistance to first-line anti-TB drugs; all the patients completed a standard nine-month anti-TB regimen and made an uneventful recovery. The patients did not have a history of thyroid and/or autoimmune disease.

Between groups comparison of measured values was made with the Kruskall-Wallis non-parametric ANOVA test while correlations abetween sIL-2R- $\alpha$ and the other thyroid function parameters were done with Spearman's rank correlation test. 


\section{Results}

One patient was hyperthyroid and presented initially with total serum thyroxine and triiodothyronine above the assays' normal limits ( $16.1 \mathrm{ng} / \mathrm{dL}$ and $2.45 \mathrm{ng} / \mathrm{mL}$ respectively, with thyrotropin at $1.52 \mu \mathrm{IU} / \mathrm{mL}$ ), remaining so after anti-TB treatment began (with serum thyroxine at 16.0 $\mathrm{ng} / \mathrm{dL}$, triiodothyronine at $2.74 \mathrm{ng} / \mathrm{mL}$ and serum thyrotropin at $2.20 \mu \mathrm{IU} / \mathrm{mL}$ ). His free triiodothyronine and s-IL-2R$\alpha$ remained normal in both samplings.

Overall hormone and s-IL-2R- $\alpha$ measurements results are presented in table 1 . Mean thyrotropin \pm SE remained well within normal limits at the first and at the second sampling. Mean total thyroxine \pm SE did not show any statistically significant differences between measurements. The observed elevation in total triiodothyronine levels (noted in $27 / 29$ patients), after two weeks of anti-TB treatment, was statistically significant (Kruskall-Wallis $p=0,05$ ). Mean \pm SE free triiodothyronine showed an increase after the initiation of anti-TB treatment, however these mean values were within normal limits and differences were not statistically significant. Mean \pm SE sIL-2R- $\alpha$ levels were higher before treatment compared to mean values after treatment began, but not up to statistical significance and within normal limits. With the exception of the hyperthyroid patient, sIL-2R- $\alpha$ levels were inversely correlated with total triiodothyronine levels before treatment (Spearman's rank correlation R:-0.62, p: 0.017), while no correlation was found at the second sampling, after two weeks of anti-TB therapy (Spearman's R: -0.11, p: 0.70). Serum thyrotropin, total thyroxine and free triiodothyronine were not correlated with sIL-2R- $\alpha$ neither before nor after the initiation of anti-TB therapy.

Table 1: Overall hormone and soluble interleukin-2 receptor measurements results of the patients $(n=29)$ included in the study

\begin{tabular}{|l|c|c|}
\hline Measured parameter & $\begin{array}{c}1^{\text {st }} \text { sampling } \\
(\text { mean } \pm \text { SE) }\end{array}$ & $\begin{array}{c}\text { nd } \text { sampling } \\
(\text { mean } \pm \text { SE) }\end{array}$ \\
\hline Thyrotropin (in $\mu \mathrm{IU} / \mathrm{mL})$ & $1.07 \pm 0.15$ & $1.09 \pm 0.15$ \\
\hline total thyroxine $($ in $\mathrm{ng} / \mathrm{dL})$ & $9.91 \pm 0.41$ & $9.89 \pm 0.41$ \\
\hline total triiodothyronine $(\mathrm{in} \mathrm{ng} / \mathrm{mL})$ & $0.98 \pm 0.06$ & $1.29 \pm 0.08^{*}$ \\
\hline free triiodothyronine $($ in $\mathrm{pg} / \mathrm{mL})$ & $1.73 \pm 0.05$ & $1.91 \pm 0.07$ \\
\hline soluble interleukin-2 receptor $(\mathrm{in} \mathrm{pg} / \mathrm{mL})$ & $1832 \pm 174$ & $1805 \pm 129$ \\
\hline
\end{tabular}

* comparison of parameters' results between samplings significant at the $p=0.05$ level (Kruskall-Wallis non-parametric ANOVA).

\section{Discussion}

This study's patients initially presented with low to normal serum total triiodothyronin levels, which, following anti-TB treatment, showed a small but statistically significant elevation. This is a finding compatible with the low T3 syndrome (euthyroid sick syndrome) encountered in non-thyroidal disease (8). A significant negative correlation was observed between serum total triiodothyronine and sIL-2R- $\alpha$ in patients with TB, a non-thyroidal disease, before administration of anti-TB treatment. Consistently high levels of sIL-2R have been found in patients with untreated Graves' disease and toxic adenoma (4), while low levels of sIL-2R have been consistently measured in hypothyroid post-thyroidectomy patients (4) and reported in cases of autoimmune thyroiditis (10). Levels of sIL-2R have been shown to be affected essentially in severe cases of TB and in immunocompromised patients (9). The patients of this study were not immunocompromised and made an uneventful recovery, so in this setting, we can also speculate (given the small overall variations), a relation between thyroid hormones and sIL-2R in the low-T3 syndrome. Since the measurement of sIL-2R has already been proposed as an indicator of disease activity in Graves' disease (11) and an early response marker in thyrotoxicosis' treatment (5), further relevant studies can be envisaged, in order to assess the behavior and clinical utility of sIL-2R levels versus thyroid function parameters in non-thyroidal disease.

\section{Conclusion}

Soluble serum interleukin-2 receptor alpha levels were found to be inversely correlated with total triiodothyronine levels in 29 -otherwise healthy- patients with pulmonary tuberculosis and the low-T3 syndrome before the administration of antimicrobial therapy. Further studies can be envisaged, in order to assess the behavior and clinical utility of this receptor's levels versus thyroid function parameters in non-thyroidal disease.

\section{References}

1. Theze J, Alzari PM, Bertoglio J. Interleukin 2 and its receptors: recent advances and new immunological functions. Immunol Today 1996;10:481-6.

2. Rubin LA, Nelson DL. The soluble interleukin-2 receptor: biology, function and clinical application. Ann Intern Med 1990;113:619-28.

3. Chrobak L. Clinical significance of soluble interleukin-2 receptor. Acta Med (Hradec Kralove) 1996;39:3-6.

4. Mariotti S, Caturegli G, Barbesino $\mathrm{G}$ et al. Thyroid function and thyroid autoimmunity independently modulate serum concentration of soluble interleukin 2 (IL 2) receptor (sIL-2R) in thyroid diseases. Clin Endocrinol 1992;37:415-22.

5. Smallridge RC, Tsokos GC, Burman KD et al. Soluble interleukin-2 receptor is a thyroid hormone-dependent early response marker in the treatment of thyrotoxicosis. Clin Diagn Lab Immunol 1997;4:583-6.

6. Chow CC, Mak TW, Chan CH, Cockram CS. Euthyroid sick syndrome in pulmonary tuberculosis before and after treatment. Ann Clin Biochem 1995;32:385-91.

7. Hill AR, Schmidt FJ, Schussler GC. Rapid changes in thyroid function tests upon treatment of tuberculosis. Tub Lung Dis 1995;76:223-9.

8. Ilias I, Tselebis A, Boufas A, Panoutsopoulos G, Filippou N, Christakopoulou J. Pulmonary tuberculosis and its therapy do not significantly affect thyroid function tests. Int J Clin Pract 1998;52:227-8.

9. Takahashi S, Setoguchi Y, Nukiwa T, Kira S. Soluble interleukin-2 receptor in sera of patients with pulmonary tuberculosis. Chest 1991;99:310-4.

10. Loviselli A, Calia MA, Murenu S, Mossa P, Cambosu MA, Caradonna A. Circulating soluble IL-2 receptor levels are low in patients with hypothyroid autoimmune thyroiditis. Horm Metab Res 1994;26:548-51.

11. Komorowski J, Jankiewicz J, Robak T, Blasinska-Morawiec M, Stepien H Cytokines serum levels as the markers of thyroid activation in Graves' disease. Immunol Lett 1998;60:143-8.

Submitted October 1998

Accepted April 1999

Dr. Ioannis Ilias, 129 Kifissias Avenue, Athens GR-11524, Greece. e-mail: ilias@compulink.gr 